\title{
Hemoglobin Trend in Critically Ill Patients with Long ICU Stay
}

\author{
Ioana Grigoras ${ }^{1,2^{*}}$, Oana C Chelarescu ${ }^{3}$, Daniel M Rusu ${ }^{2}$ and Irina Ristescu ${ }^{1}$ \\ ${ }^{1}$ University of Medicine and Pharmacy "Gr. T. Popa”, lasi, Romania \\ ${ }^{2}$ Anesthesia and Intensive Care Department, Regional Institute of Oncology, lasi, Romania \\ ${ }^{3}$ Anesthesia and Intensive Care Department, Centre Hospitalier Universitaire Caen, France
}

"Correspondence author: loana Griogras, MD, PhD, Associate Professor of Anesthesia and Intesnsive Care, Anesthesia and Intensive Care Department, Regional Institute of Oncology, lasi, Romania, General Henri Mathias Berthelot Street, No 2-4, 700483, lasi, Romania, Tel: +40 (0) 3742788 ;0 ; E-mail: ioana.grigoras.ro@gmail.com

Received date: 10 December 2013, Accepted date: 27 February 2014, Published date: 9 May 2014

Copyright: ( 2014 Griogras I, et al. This is an open-access article distributed under the terms of the Creative Commons Attribution License, which permits unrestricted use, distribution, and reproduction in any medium, provided the original author(s) and source are credited.

\begin{abstract}
Introduction: Critically ill patients develop anemia due to several reasons: bleeding prior or during intensive care unit (ICU) stay, frequent flebotomies, hemodilution and inflammatory status with altered erythropoiesis. The aim of this study was to assess the trend of hemoglobin $(\mathrm{Hb})$ level during long ICU stay (more than 7 days) in transfused and nontransfused patients.
\end{abstract}

Materials and Methods: We conducted a prospective observational study that included all patients with long ICU length of stay (LOS) admitted during 1 year in a 19-beds mixed ICU of a tertiary care university hospital. Patients were divided into two groups: never transfused (NT) and ever transfused (ET) according to their transfusional status during ICU stay. Collected data: demographic data, severity scores, Hb values during ICU stay transfusion status and outcome. Statistical analysis was conducted with SPSS 15.0.

Results: 132 patients (54 NT, $78 \mathrm{ET}$ ) were enrolled in the study. On ICU admission, overall mean $\mathrm{Hb}$ level was $9.2 \mathrm{~g} \%(95 \% \mathrm{Cl}$ 8.72-9.72) with a significant difference between NT and ET group (10.1 g\% versus $8.5 \mathrm{~g} \% ; \mathrm{p}<0.01)$. By the day 7 there was little change in overall mean $\mathrm{Hb}$ value $(9.1 \mathrm{~g} \% ; 95 \% \mathrm{Cl} 8.85-9.43)$ as in $\mathrm{NT}$ group the $\mathrm{Hb}$ values continued to drop while in ET group raised as a result of transfusions. However, at two weeks after ICU admission there was a significant decrease in mean $\mathrm{Hb}$ value, from $9.2 \mathrm{~g} \%$ in day 1 to $8.1 \mathrm{~g} \%(95 \% \mathrm{Cl} 7.71-8.49)$ in day 14. The variance also had a significant decrease over time (8.94 in day $1 ; 1.58$ in day 14$)$ indicating a convergence of $\mathrm{Hb}$ values in studied patients, regardless of their transfusion status.

Conclusions: Despite the fact that $\mathrm{Hb}$ values on ICU admission may vary widely, after 14 days of ICU stay the $\mathrm{Hb}$ values tend to converge. The $\mathrm{Hb}$ level in critically ill patients with long ICU stays decreases stadly over time no matter the transfused or non-transfused status.

Keywords: Critical Ill Patients; Anemia; Transfusion; Hemoglobin; Intensive Care

\section{Introduction}

Anemia, highly prevalent (75-98\%) in critically ill patients, is associated with increased health care resource use and may be associated with poor patient outcomes [1]. Hemoglobin levels continue to drop during ICU stay [2].

Critically ill patients develop anemia due to several reasons: bleeding prior or during Intensive Care Unit (ICU) stay, frequent phlebotomies, inflammatory status with altered erythropoiesis, hemodilution [3-7]. The most common treatment of anemia in critically ill patients is blood transfusions. Taking into account the benefits and risks of transfusion, the decision to transfuse or not is a matter of continuous debate [3,4,7-9]. Despite the fact that hemoglobin $(\mathrm{Hb})$ levels and transfusion practices have been the aim of many studies, most of them characterize the ICU patients with shortto-moderate Length of Stay (LOS) or particular groups of ICU patients $[4,7,9,10]$. For critically ill patients with prolonged ICU stay such data are still needed. Moreover, evidences suggest that a greater $\mathrm{Hb}$ variability overtime is independently associated with a higher mortality rate in end stage renal disease patients [11]. The aim of our study was to assess the trend of hemoglobin value in critically ill patients with long ICU LOS (more than 7 days) with respect to transfusion status.

\section{Material and Methods}

We conducted a prospective, single center observational study in a 19-beds mixed ICU of an adult tertiary care hospital, over one year. Patients admitted to ICU were critically ill, surgical, medical or trauma patients. All patients admitted to ICU during a 12 months period, with a continuous length-of-stay (LOS) of more than 7 days were enrolled in the study (132 patients). For each patient demographic data (age, gender, admission type), Acute Physiology and Chronic Health Evaluation (APACHE) II scores, Sequential Organ Failure Assessment (SOFA) scores, daily hemoglobin values and transfusion status were recorded. For all transfused patients, further information regarding transfusion trigger, number of red blood cells (RBC) units during each transfusion event and ICU LOS before first transfusion were collected. Outcome variables including ICU LOS and mortality were recorded. 
Citation: Grigoras I, Chelaresu OC, Rusu DM, Ristescu I. Hemoglobin Trend in Critically III Patients with Long ICU Stay. Journal of Surgery [Jurnalul de Chirurgie] 2014; 10(1): 63-67. doi: 10.7438/1584-9341-10-1-12

Patients were divided into two groups: never transfused (NT - 54 patients; 40.9\%) and ever transfused (ET-78 patients, 59.1\%).

Statistical analysis was conducted using SPSS version 15.0 for Windows and Microsoft Office Excel. Continuous variables were summarized as mean \pm Standard Deviation (SD) for normally and non-normally distributed variables. Comparisons between ET and NT patients were conducted using Student's $t$-test or Wilcoxon's test for normally and non-normally distributed continuous variables, respectively. $\chi 2$ or Fisher's exact test were used to compare categorical variables. 95\% reference range (95\% RR) and 95\% confidence interval (95\% CI) were calculated for the mean hemoglobin values on admission and sequentially after (day 7, 14 and 21). Kernel curves for the hemoglobin values on admission and day 14 were drawn and variance was calculated.

\section{Results}

During 12 months study period 132 patients with more than 7 days ICU LOS were enrolled. The average age in the study group was $62.8 \pm$
16.5 years old. The majority of patients were men (59.1\%) admitted to the ICU for surgical reasons (82.6\%). Mean APACHE II and SOFA scores on admission were $17.2 \pm 8.2$ and $5.8 \pm 2.9$ respectively. Overall, mean ICU LOS was $12.9 \pm 5.5$ days and mortality rate reached $47 \%$. More than half of the critically ill patients with long ICU LOS (78 patients, 59.1\%) received one or more red blood cells (RBC) units during their ICU stay.

No statistical differences regarding age, admission type and severity scores on admission were found between the NT and ET groups. However, patients receiving transfusions had higher SOFA scores later on during ICU LOS. Mean "worst" SOFA score was $9.8 \pm 4.5$ in ET group versus $8.9 \pm 3.6$ in NT group $(\mathrm{P}=0.04)$. Mortality rate was also found to be higher in patients receiving transfusions when compared to non-transfused patients $(65.4 \%$ versus $20.4 \%$; $\mathrm{P}=0.04)$. Baseline information regarding demographics data and outcome variables of patients enrolled in the study are summarized in Table 1.

Table I: Patient's data.

\begin{tabular}{|c|c|c|c|c|}
\hline & All Patients & Never Transfused & Ever Transfused & P Value \\
\hline & $132(100 \%)$ & $54(40.9 \%)$ & $78(59.1 \%)$ & \\
\hline Age (years) - mean $\pm S D$ & $62.8 \pm 16.5$ & $65.7 \pm 14$ & $60.4 \pm 17.6$ & 0.07 \\
\hline Gender male - no.(\%) & $78(59.1 \%)$ & $30(55.6 \%)$ & $48(61.5 \%)$ & 0.48 \\
\hline \multicolumn{5}{|l|}{ Admission type - no.(\%) } \\
\hline surgery & $109(82.6 \%)$ & $49(90.7 \%)$ & $60(76.9)$ & 0.56 \\
\hline emergency & $73(55.3 \%)$ & $33(61.1 \%)$ & $40(51.3 \%)$ & 0.88 \\
\hline elective & $36(27.3 \%)$ & $16(29.6 \%)$ & $20(25.6 \%)$ & 0.45 \\
\hline medical & $18(13.6 \%)$ & $5(9.3 \%)$ & $13(16.7 \%)$ & - \\
\hline trauma & $5(3.8 \%)$ & $0(0 \%)$ & $5(6.4 \%)$ & - \\
\hline \multicolumn{5}{|l|}{ Severity of the disease } \\
\hline APACHE II on admission -mean \pm SD & $17.2 \pm 8.2$ & $16.9 \pm 8.3$ & $17.4 \pm 8.1$ & 0.36 \\
\hline APACHE II worst - mean \pm SD & $22.7 \pm 9.7$ & $23.3 \pm 9.5$ & $22.2 \pm 9.8$ & 0.58 \\
\hline SOFA on admission - mean \pm SD & $5.8 \pm 2.9$ & $5.5 \pm 3$ & $6.2 \pm 2.8$ & 0.83 \\
\hline SOFA worst - mean \pm SD & $9.4 \pm 4.1$ & $8.9 \pm 3.6$ & $9.8 \pm 4.5$ & 0.04 \\
\hline \multicolumn{5}{|l|}{ Outcome } \\
\hline ICU LOS (days) - mean \pm SD & $12.9 \pm 5.5$ & $12.8 \pm 4.6$ & $13 \pm 6.1$ & 0.88 \\
\hline ICU mortality - no. (\%) & $62(47 \%)$ & $11(20.4 \%)$ & $51(65.4 \%)$ & 0.04 \\
\hline
\end{tabular}

The 78 patients of ET group were transfused in 154 different occasions with one or more RBC units. Half of them (51.3\%) were transfused in the first 24 hours after ICU admission, and only $6.4 \%$ had their first transfusion after one week of ICU stay. Mean transfusion trigger $\mathrm{Hb}$ was $7.8 \pm 2.3 \mathrm{~g} \%$. Most of the patients received 3 units of RBC in 2 different occasions and had a mean $\mathrm{Hb}$ increase of $0.9 \mathrm{~g} \%$ after each transfusion event. Transfusion requirements during ICU LOS were higher in the first 2 days following admission and decreased after this period. The total number of RBC units used during the 12 months study period for critically ill patients with long ICU stay was 228 . The informations regarding transfusion policy are summarized in Table 2.

Table II: Transfusion policy.

\begin{tabular}{|l|l|}
\hline ICU LOS before first transfusion - no. of pts (\%) & \\
\hline$<1$ day & $40(51.3 \%)$ \\
\hline
\end{tabular}


Citation: Grigoras I, Chelaresu OC, Rusu DM, Ristescu I. Hemoglobin Trend in Critically III Patients with Long ICU Stay. Journal of Surgery [Jurnalul de Chirurgie] 2014; 10(1): 63-67. doi: 10.7438/1584-9341-10-1-12

Page 65

\begin{tabular}{|l|l|}
\hline 1-7 days & $33(42.3 \%)$ \\
\hline$>7$ days & $5(6.4 \%)$ \\
\hline Transfusion trigger $\mathrm{Hb}(\mathrm{g} \%)$ - mean $\pm \mathrm{SD}$ & $7.8 \pm 2.3$ \\
\hline Transfusion events/pacient - mean $\pm \mathrm{SD}$ & $2 \pm 1.2$ \\
\hline RBC units transfused/patient - mean $\pm \mathrm{SD}$ & $2.9 \pm 2.4$ \\
\hline Post transfusion $\mathrm{Hb}(\mathrm{g} \%)$ - mean $\pm \mathrm{SD}$ & $8.3 \pm 1.9$ \\
\hline Mean Hb increase/transfusion event - g\% & 0.9 \\
\hline 78 ever transfused patients; 154 transfusion events - 228 RBC units \\
\hline
\end{tabular}

Overall, mean $\mathrm{Hb}$ value on admission was $9.2 \pm 3 \mathrm{~g} \%$. There was a statistically significant difference in mean $\mathrm{Hb}$ on admission in NT patients versus ET patients $(10.1 \mathrm{~g} \%$ versus $8.5 \mathrm{~g} \%$; $\mathrm{P}<0.01)$. However the prevalence of anemia $(\mathrm{Hb}<12 \mathrm{~g} \%)$ on ICU admission was high in both groups ( $74.1 \%$ in NT patients, $89.7 \%$ in ET patients). Moderate and severe anemia on admission had higher prevalence rates in transfused than in non-transfused patients (moderate anemia $21.8 \%$ versus $13 \%$; severe anemia $20.5 \%$ versus $7.4 \%$, respectively) without reaching statistical significance $(\mathrm{P}=0.84$ and $\mathrm{P}=0.93$ respectively). Prevalence of anemia on ICU discharge was even higher than on admission $(95.4 \%$ compared to $83.3 \%, \mathrm{P}<0.01)$ both in the NT $(94.4 \%$ versus $74.1 \%, \mathrm{P}<0.01)$ and $\mathrm{ET}$ patients $(96.1 \%$ versus $89.7, \mathrm{P}=0.2)$. Table III summarizes these data.

Table III: Prevalence of anemia.

\begin{tabular}{|c|c|c|c|c|}
\hline & All Patients & Never Transfused & Ever Transfused & P Value \\
\hline & $132(100 \%)$ & $54(40.9 \%)$ & $78(59.1 \%)$ & \\
\hline $\mathrm{Hb}(\mathrm{g} \%)$ on ICU admission - mean $\pm \mathrm{SD}$ & $9.2 \pm 3$ & $10.1 \pm 3.3$ & $8.5 \pm 2.8$ & $<0.01$ \\
\hline Anemia - on ICU admission - no.(\%) & $110(83.3 \%)$ & $40(74.1 \%)$ & $70(89.7 \%)$ & 0.11 \\
\hline $\mathrm{Hb}=12-8 \mathrm{~g} \%$ & $66(50 \%)$ & $29(53.7 \%)$ & $37(47.4 \%)$ & 0.14 \\
\hline $\mathrm{Hb}=7,9-6 \mathrm{~g} \%$ & $24(18.2 \%)$ & $7(13 \%)$ & $17(21.8 \%)$ & 0.84 \\
\hline $\mathrm{Hb}<6 \mathrm{~g} \%$ & $20(15.1 \%)$ & $4(7.4 \%)$ & $16(20.5 \%)$ & 0.93 \\
\hline $\mathrm{Hb}(\mathrm{g} \%)$ on ICU discharge - mean $\pm \mathrm{SD}$ & $8.5 \pm 1.9$ & $8.6 \pm 1.9$ & $8.4 \pm 1.9$ & 0.47 \\
\hline Anemia - at ICU discharge - no.(\%) & $126(95.4 \%)$ & $51(94.4 \%)$ & $75(96.1 \%)$ & 0.64 \\
\hline $\mathrm{Hb}=12-8 \mathrm{~g} \%$ & $74(56.1 \%)$ & $32(59.2 \%)$ & $42(53.8 \%)$ & 0.82 \\
\hline $\mathrm{Hb}=7,9-6 \mathrm{~g} \%$ & $43(32.6 \%)$ & $15(27.8 \%)$ & $28(35.9 \%)$ & 0.13 \\
\hline $\mathrm{Hb}<6 \mathrm{~g} \%$ & $9(6.8 \%)$ & $4(7.4 \%)$ & $5(6.4 \%)$ & 0.18 \\
\hline
\end{tabular}

ICU course of $\mathrm{Hb}$ levels, according to admission $\mathrm{Hb}$ range, as well as the trend of mean $\mathrm{Hb}$ value in transfused and non-transfused patients, reveals the tendency of convergence toward a value a little higher than the transfusion trigger (Figures 1 and 2).

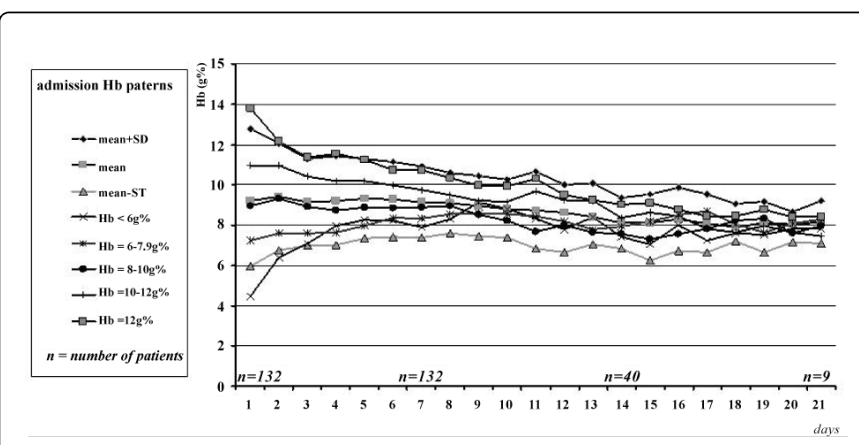

Figure 1: ICU course of $\mathrm{Hb}$ levels according to admission $\mathrm{Hb}$ range.

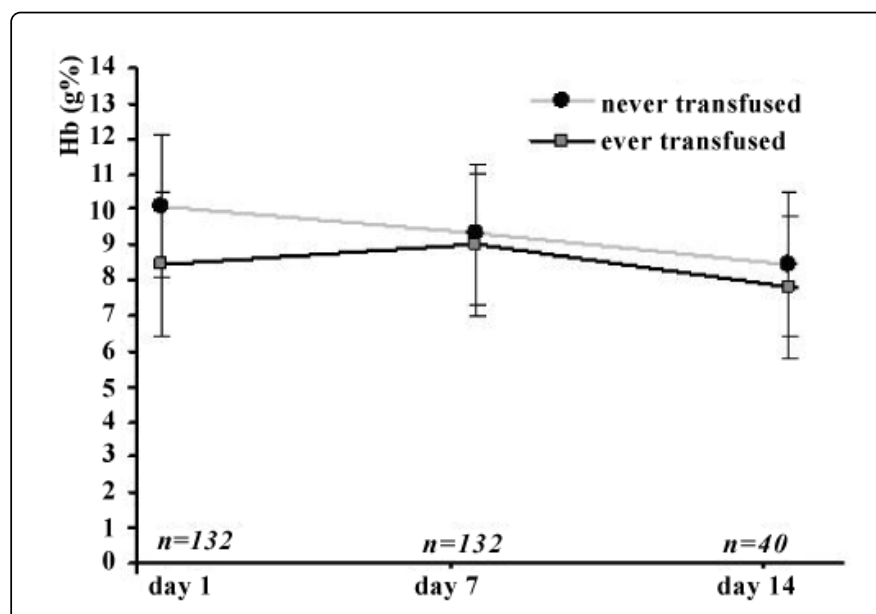

Figure 2: ICU course of mean $\mathrm{Hb}$ level in NT and ET groups.

On admission mean $\mathrm{Hb}$ level was $9.2 \mathrm{~g} \%$ (95\% CI 8.72-9.72) with a significant difference between NT and ET group (10.1 g\% versus $8.5 \mathrm{~g}$ 
$\% ; \mathrm{P}<0.01)$. By the day 7 there was little change in mean $\mathrm{Hb}$ value $(9.1$ $\mathrm{g} \%$; 95\% CI 8.85-9.43) as in NT group the Hb values continued to drop while in ET group raised as a result of transfusions. However, at two weeks after ICU admission there was a significant decrease in mean $\mathrm{Hb}$ value, from $9.2 \mathrm{~g} \%$ in day 1 to $8.1 \mathrm{~g} \%$ (95\%CI 7.71-8.49) in day 14 . The variance also had a significant decrease over time (8.94 in day 1; 1.58 in day 14) indicating a convergence of $\mathrm{Hb}$ values in studied patients, regardless of their transfusion status. The convergence of $\mathrm{Hb}$ levels over time, no matter the transfusion status or admission $\mathrm{Hb}$ level is shown by the Kernel curves of distribution of $\mathrm{Hb}$ values in 1st day and 14th day of ICU LOS (Figure 3).

\section{Discussion}

Our study evaluated the time course of $\mathrm{Hb}$ values in critically ill patients with long ICU LOS. All patients with more than one week of ICU LOS were followed up, no matter the transfusion status. Other studies had already revealed that $\mathrm{Hb}$ concentration decreases over time during ICU stay $[3,4,7,12]$. Most of them concern all ICU patients no matter the duration of ICU LOS.

As other authors, we found a high prevalence of anemia on ICU admission that persisted during ICU LOS [3,7,12-14]. This could be partially explained by the restrictive blood transfusion policy applied in our ICU, mean \pm SD transfusion trigger Hb being $7.8 \pm 2.3 \mathrm{~g} \%$.

Transfusion requirements during ICU LOS were higher in the first 2 days following admission. One reason might be the high proportion of surgical patients included in our study. Another explanation is the necessity of a complete evaluation of a patient on ICU admission which involve placement of invasive devices and frequent phlebotomies.

Time course of $\mathrm{Hb}$ levels revealed a tendency of convergence to a value a little higher than the transfusion trigger. This seems to be explainable as the drop in the $\mathrm{Hb}$ concentration over time in NT patients was never compensated as they didn't reach the transfusion trigger $\mathrm{Hb}$, while in the ET patients; transfusions were used only when the risk of decreased oxygen carrying capacity was considered to exceed the risk of transfusion. However, this is not the only possible explanation as there was a significant drop in transfusion requirements in the first week of ICU stay. Persisting inflammation in critically ill patients with long ICU LOS might be another cause for sustained anemia $[1,15,16]$. As the outliers may have a significant influence on the results when analyzing the trend of mean $\mathrm{Hb}$ value over time in a group drawn from a population, we tried to overcome this problem by analyzing the variance and the Kernel curves of distribution of $\mathrm{Hb}$ concentrations in patients enrolled in the study. Another factor that might influence the data, the unavoidable fall in the number of patients over time, was minimized by choosing the day 14 as a comparing point for the admission $\mathrm{Hb}$ variance in studied patients, as after this day there was an unacceptable low number of patients for comparison. The fact that the variance also had a significant decrease over time (8.94 in day $1 ; 1.58$ in day 14) clearly reflects that in critically ill patients with long ICU stay there is a tendency of convergence of $\mathrm{Hb}$ levels to a value a little higher than the transfusion trigger $\mathrm{Hb}$ no matter the transfusion status.

Recent observational studies do show an important adverse effect of RBC transfusion on mortality, but even the best conducted adjustments for confounding cannot completely eliminate its impact $[10,17]$. In our study we found no difference on the severity of the disease on admission between groups, as reflected by APACHE II and
SOFA scores. However transfused patients had higher SOFA scores during their ICU LOS and a higher mortality rate.

\section{Conclusions}

Based on our results, we conclude that despite the fact that $\mathrm{Hb}$ values of critically ill patients may vary widely at ICU admission, after 14 days of ICU stay the $\mathrm{Hb}$ values tend to converge to a level closed to the transfusion trigger $\mathrm{Hb}$, no matter the transfusion status. The ICU LOS and transfusion policy influence the $\mathrm{Hb}$ level of patients at ICU discharge.

\section{Conflict of Interests}

Authors have no conflict of interests to disclose.

\section{References}

1. Hayden SJ, Albert TJ, Watkins TR, Swenson ER (2012) Anemia in critical illness: insights into etiology, consequences, and management. Am J Respir Crit Care Med 185: 1049-1057.

2. Thomas J, Jensen L, Nahirniak S, Gibney RT (2010) Anemia and blood transfusion practices in the critically ill: a prospective cohort review. Heart Lung 39: 217-225.

3. Chant C, Wilson G, Friedrich JO (2006) Anemia, transfusion, and phlebotomy practices in critically ill patients with prolonged ICU length of stay: a cohort study. Crit Care 10: R140.

4. Corwin HL, Gettinger A, Pearl RG, Fink MP, Levy MM, et al. (2004) The CRIT Study: Anemia and blood transfusion in the critically ill--current clinical practice in the United States. Crit Care Med 32: 39-52.

5. Corwin HL, Parsonnet KC, Gettinger A (1995) RBC transfusion in the ICU. Is there a reason? Chest 108: 767-771.

6. Fink MP (2004) Pathophysiology of intensive care unit-acquired anemia. Crit Care 8 Suppl 2: S9-10.

7. Vincent JL, Baron JF, Reinhart K, Gattinoni L, Thijs L, et al. (2002) Anemia and blood transfusion in critically ill patients. JAMA 288: 1499-1507.

8. Vincent JL, Sakr Y, Sprung C, Harboe S, Damas P; Sepsis Occurrence in Acutely Ill Patients (SOAP) Investigators (2008) Are blood transfusions associated with greater mortality rates? Results of the Sepsis Occurrence in Acutely Ill Patients study. Anesthesiology 108: 31-39.

9. Hebert PC, Wells G, Blajchman MA, et al. (1999) A multicenter, randomized, controlled clinical trial of transfusion requirements in critical care. Transfusion Requirements in Critical Care Investigators, Canadian Critical Care Trials Group. N Engl J Med. 340: 409-417.

10. Zilberberg M, Lee S, Wiederkehr D, et al. (2008) Anemia, transfusions and hospital outcomes among critically ill patients on prolonged acute mechanical ventilation: a retrospective cohort study. Critical Care. 12: R60.

11. Yang W, Israni RK, Brunelli SM, Joffe MM, Fishbane S, et al. (2007) Hemoglobin variability and mortality in ESRD. J Am Soc Nephrol 18: 3164-3170.

12. Nguyen BV, Bota DP, Mélot C, Vincent JL (2003) Time course of hemoglobin concentrations in nonbleeding intensive care unit patients. Crit Care Med 31: 406-410.

13. Walsh TS, Lee RJ, Maciver CR, Garrioch M, Mackirdy F, et al. (2006) Anemia during and at discharge from intensive care: the impact of restrictive blood transfusion practice. Intensive Care Med 32: 100-109.

14. Carson JL, Hill S, Carless P, Hébert P, Henry D (2002) Transfusion triggers: a systematic review of the literature. Transfus Med Rev 16: 187-199.

15. Rogiers P, Zhang H, Leeman M, Nagler J, Neels H, et al. (1997) Erythropoietin response is blunted in critically ill patients. Intensive Care Med 23: 159-162. 
Citation: Grigoras I, Chelaresu OC, Rusu DM, Ristescu I. Hemoglobin Trend in Critically III Patients with Long ICU Stay. Journal of Surgery [Jurnalul de Chirurgie] 2014; 10(1): 63-67. doi: 10.7438/1584-9341-10-1-12

Page 67

16. Krafte-Jacobs B1, Levetown ML, Bray GL, Ruttimann UE, Pollack MM (1994) Erythropoietin response to critical illness. Crit Care Med 22: 821-826.

17. Hopewell S, Omar O, Hyde C, Yu LM, Doree C, et al. (2013) A systematic review of the effect of red blood cell transfusion on mortality: evidence from large-scale observational studies published between 2006 and 2010 BMJ Open 3. 